\title{
WELFARE STATE AS ONE OF THE PRINCIPAL FACTORS DRIVING POST-WAR EUROPEAN INTEGRATION PROCESS ${ }^{1}$
}

\author{
Milan KATUNINEC \\ Professor, Department of Political Science \\ Trnava University, Slovakia \\ E-mail: milan.katuninec@truni.sk \\ Lenka DIENER \\ Research Assistant, Department of Sociology \\ Trnava University, Slovakia \\ E-mail: lenka.diener@truni.sk
}

\begin{abstract}
The modern welfare state, as it is understood today, has become a topical issue in many Western European countries, especially after the worldwide economic depression of the 1930s and World War II, the most destructive armed conflict in the history of humanity. The presented study offers several perspectives on the welfare state model in the Western European environment at the beginning of the process of European integration. Although after the war, influential Western European politicians have accepted the importance of the welfare state, there is no single welfare state model in Europe. The study has no ambition to provide a detailed analysis of social models in Europe. It deals with several models of the welfare state, paying particular attention to Germany and France, whose relations became the engine of the integration process in Europe, which was, from the start, both a political and an economic project.
\end{abstract}

Key words: Europe, Welfare state, social model, the Federal Republic of Germany, France, post-war European integration

1 This paper is an outcome of the VEGA scientific project No. VEGA 1/0131/18 entitled Europe in Movement. Multicausality of Present Democracy Crisis and the Rise of Extremism in Europe. 


\section{Introduction}

The World War II (1939-1945) brought unprecedented destruction and loss of lives and it caused a deep-seated trauma in both Eastern and Western Europe. This trauma in Europe was also associated with the negative effects of the Great Depression, which in some European countries lasted until the beginning of the War. Post-war poverty, hunger, and enormous damage done to the infrastructure, industry and agriculture influenced the political shift to the left not only in Eastern Europe which fell under the influence of the Soviet Union but also in Western European countries. The negative consequences of the economic crisis and war have forced Western European political parties to develop strategic plans and social models providing a safety net for everyone. Although several Western European countries had negative experiences with a policy of not interfering in a free-market environment and influential Western European politicians have accepted the importance of the welfare state, after the war they did not create one common welfare state model in Europe. Despite the fact that the attraction of left-wing ideas was real in many countries of Western Europe, the driving forces behind the post war process of European integration became the Christian Democratic politicians of France and the Federal Republic of Germany, whose political strategy was linked in particular to the recovery of social and economic conditions in their own countries.

\section{Material and methods}

The proposed study seeks to point out some Europe's social models that had the ambition to provide a safety net to all their citizens. Although Western European countries did not adopt a single welfare state model, they had to pay close attention to many of the same social problems after the war. The main aim of the study is to highlight that the welfare state has become one of the main factors driving the post-war European integration process. The sources in our research are predominantly documents, books and studies of internationally recognized authors. In the study a historical, comparative and analytical research method is used. We also tried to combine chronological and thematic approaches.

\subsection{Results and discussion}

The process of European integration is associated with several (often divergent) attempts to promote a single European social model. Interest in this issue in the post-war period was influenced by experience with the policy of non-interference in the free-market environment and with the deepest economic crisis in modern European history. After World War II, many regions in Europe were destroyed, and politicians, along with respected theorists, offered citizens their ideas on how to prevent a repeat of the Great Depression and how to pave the way to European integration. In particular, the negative social and economic impact of World War II on the European population influenced the political shift to the left in many European countries. Some leftist concepts of the European social and political integration raised concerns in the West about the growing popularity of communist parties. Therefore, American political 
representatives who came with an offer an economic recovery to the devastated European economy put pressure on several countries to strengthen the position of conservative parties. With the support of the Marshall Plan, the concept of a social market economy had begun to be promoted in many Western European countries (Katuninec, 2020: 176-177).

The purpose of this study is not to provide a detailed analysis of postwar social models in Europe, but to point out that Europe's rebirth after World War II and the beginning of European integration is linked to the building of a modern welfare state. The Study deals with several models of the welfare state, paying particular attention to Germany and France, whose relations became the engine of the integration process in Europe, which was from the start both a political and an economic project. Franco-German reconciliation was undoubtedly important for all of Europe because it provided the initial condition for the organizational structure of Europe (Gerbet, 2004: 70). The basic idea of the integration process became an effort to preserve the peace and security of European countries by connecting their interests in political, economic, social and cultural areas with the aim of strengthening Europe's influence and competitiveness in world affairs and rejecting policies that revive past disputes and evoke national passions in neighbourhood relations of European countries.

\section{3. 'Golden Age' of welfare state}

Although the first pillars of social protection developed in Western Europe already at the end of the nineteenth century, the modern welfare state, "as it is understood today, originated in the early 1940s and developed especially in the post war period" (Ştefan, 2015: 26). The post-war social system of many Western European countries was influenced by the British Plan for Social Security developed already during the war by a team of experts chaired by the economist William Beveridge. The Beveridge system, funded primarily from the state budget, provided a summary of principles necessary to banish poverty and its ambition was to include all citizens (see Beveridge Report, November 1942; Social Insurance and Allied Services, 1942). After the election victory in July 1945, the Labour Party in Britain focused on the slogan "the third force" and now entered the pre-election match with the slogan a "United Socialist States of Europe". The Movement for the Socialist United States of Europe was formed in Montrouge, near Paris, in June 1946. However, the Cold War rivalry between the United States and the Soviet Union significantly weakened all post-war ideas and plans for a socialist program for an independent united social Europe. In the Western European environment, political attention has focused mainly on the reconciliation between France and West Germany, which has become the engine of the integration process in Europe. Nevertheless, the welfare state remained one of the most important topics in almost all Western European countries. Western European politicians, who took responsibility for their countries in the difficult post-war period, were well aware that "the social rights, income security, equalization, and eradication 
of poverty that a universalistic welfare state pursues are a necessary precondition for the strength and unity that collective power mobilization demands" (Esping-Andersen, 1990: 16).

\subsection{The post-war idea of a socialist Third Force}

After the war, communist parties gained a relatively strong position in the political life of several European countries, which Stalin tried to use to influence political events in Western Europe. The initial political influence of the communists, who became popular in particular thanks to their active involvement in the internal resistance, also came from their alliance with the social democratic parties, which likewise strengthened their own positions and took part in government coalitions. The Soviet Union, in an effort to take advantage of the popularity of communism, wanted to get the global trade union movement under its influence through the World Federation of Trade Unions. The first step towards establishing its headquarters was the formation of the Anglo-Soviet Trade Union Committee in 1941. In February 1945, an international trade union conference took place in London, at which it was agreed that a trade union of all ideological currents should operate in the new World Trade Union headquarters. Christian-oriented trade unions expressed the opinion that such a headquarters had no hope of long-term existence. Nevertheless, at the First World Trade Union Congress on 3 October 1945 in Paris, a headquarters called the World Federation of Trade Unions was established, in which, however, contradictions gradually began to appear between social democratic organizations and the efforts of communist-oriented trade unions to promote accents of class antagonism and the anti-capitalist struggle. The tensions that escalated within the World Federation of Trade Unions ended in a split during the Cold War, but in Western European countries, communist trade union headquarters maintained an influential position in the trade union movement.

As we mentioned, after the war, the left-wing politics grew in popularity. During this period, communism became a global phenomenon. Also, moderate left-wing politicians who sought to prevent the division of Europe emphasized that the future in Europe belongs to the Socialists. The president of the Movement for the Socialist United States of Europe, André Philip (1902-1970), was a member of the French Section of the Workers' International (Section française de l'Internationale ouvrière, SFIO), French socialist party founded in 1905, which was replaced in 1969 by Socialist Party (Parti socialiste). During the war Philip cooperated with General Charles de Gaulle and served in 1942 as Interior Minister under the Free French provisional government in London and Algeria. In the legislative elections of 1945, SFIO emerged as the second largest in the country, and it entered a coalition government with the French Communist Party (Parti Communiste Français, PCF) and the Christian Democratic Popular Republican Movement (Mouvement Républicain Populaire, MRP). In 1946 and part of 1947, Philip served in the French governments as Minister of the Economy, Finances and Industry. At the Conference of European Socialists held in London in February 
1947, the International Committee for the Socialist United States of Europe was founded. In the second phase, marked by the International Conference for the United Socialist States of Europe, held in Montrouge, on 21 and 22 June 1947, delegates of the Labour Party and the French Socialists were also present. And the delegation from the Union of European Federalists (UEF), together with sympathizers from several European countries, declared their support. They submitted a demand to include Germany as an equal partner in the new organization of European. According to them, only in this way could Germany be "pacified" and its population "re-educated" and returned to European values (Veber, 2012: 188). A united Europe without the participation of the Kingdom of Great Britain and the Scandinavian countries and without a German presence seemed unthinkable to the Socialists. The Second International Conference for the United Socialist States of Europe promoted the idea of a socialist "Third Force' between the United States and the Soviet Union. Jacques Robin, General Secretary to the Conference and Member of the International Executive Committee, said in this regard: "... we think that the normal standard of life in Europe, its historic past, its comprehension of the problems, will allow it, on a sound economic basis, to examine courageously the synthesis between this planned Socialist economy which the United States refuses to accept and the fundamental liberties of mankind which the U.S.S.R. neglects. We do not say a 'Third Bloc'; we would say rather a 'Third Force'. But we insist that this is not in opposition to the two others, but is a result of a synthesis between these two major terms" (Brief summary of the Second International Conference for the United Socialist States of Europe, 21-22 June 1947: 3)

The Soviet Union was the first to open up space in its occupation zone for the creation of political parties in post-war Germany. Creating political party centres in the eastern part of Berlin provided the conditions for influencing the politics of these parties. The Social Democrats from Eastern Europe were often encouraged by their Western European counterparts "to merge with the Communists, either in the innocent belief that everyone would benefit, or else in the hope of moderating Communist behaviour" (Judt, 2010: 133). The Social Democratic Party of Germany (Sozialdemokratische Partei Deutschlands, SPD) also resumed its activities and the leadership of SPD joined the action union with the communists in the Soviet zone in 1946. Voting on the question of the unification of both parties was prevented by the Soviet military authorities and took place only in the western sectors of Berlin, where unification clearly met with a negative opinion. The new party, whose founding was forced by the Soviet occupying power, was given the name the Socialist Unity Party of Germany (Sozialistische Einheitspartei Deutschlands, SED).

Among the most popular of post war German politicians was Kurt Schumacher, who had spent ten years in concentration camps. Schumacher was an opponent of the East German Socialist Unity Party and became Chairman of the revived Social Democratic Party (SPD) for the three western zones of Allied-occupied Germany. In June 1947, in a long address delivered at the party conference, Schumacher declared: "For us in Europe, despite all national and national economic excesses, the common social and economic content of the 
European countries with its clear tendency towards socialism can only be decisive". Schumacher called on the SPD to fight for socialism and emphasized that "in the future, democracy in Germany must be socialist or not at all" (see Schumacher, 1947). He was certain that his right to lead Germany would be recognized by both the Allies and the German electorate. However, the idea that the SPD under his leadership would take over governing responsibility in German post-war policy did not come to fruition.

The establishment of communist dictatorships in Eastern Europe has forced many socialists to distance themselves from doctrinal positions as well as from the idea that they may become a bridge of cooperation with the Soviet Union. The United States of America feared the expansion of the influence of communism and therefore was becoming more and more active in political life in Western Europe. In an effort to avert the threat of the possible accession of Greece and Turkey to the Soviet sphere of influence, US President Harry Truman announced in March 1947 the new direction for US foreign policy. The US intervention in Western European life was aimed at reducing the influence of the communist parties and within it the US government also took steps to ensure the exclusion of the communist parties from provisional governments in France and Italy. ${ }^{2}$ The exclusion of communists from government coalitions deepened in both countries divisions and tensions on the left-wing political scene and especially the French communists began to pursue a more militant policy. With the onset of the Cold War between the United States and Soviet Union, the idea of the Socialist United States of Europe weakened its dynamics and in the left-wing political environment of Western Europe, some concerns arose about the possible limitation of the growth of a socialist parties.

The social-democratic model, which had abandoned orthodox Marxist ideology, was seen as a compromise between the left and the right, or socialism and capitalism. This model is associated with cultural heritage, emphasizing the Lutheranism of the Scandinavian countries, with the concept of free peasants and local democracy and above all with the concept of social policy of Sweden, whose industrial development did not feel the impact of wars, because Sweden has not taken part in any war since 1814 and acted as a neutral state. An

${ }^{2}$ In France, in the first post-war elections, held on 21 October 1945, more than 5 million people cast their votes for the communists, who finished in first place with 26.1 percent of votes and 159 seats. As in France, the communists in post-war Italy were very popular. They gained strong support in the Italian general election and referendum held in 1946. The Italian Communist Party (Partito Comunista Italiano, PCI) finished in third place, behind the Christian Democracy (Democrazia Cristiana, DC) and the Socialist Party, gaining almost 19 percent and in a referendum 54 percent of Italians voted in favor of a republic. The communists in Italy also served in a governing coalition, which was led by the Christian Democrat Alcide de Gasperi. The United States played a significant part in the fact that in 1947 the communists were expelled from coalition governments in France and especially in Italy.The CIA, which financially supported the election campaign of the Christian Democrats, were also involved in the parliamentary elections held in 1948 in Italy. 
important milestone in the development of Sweden's political system (and Norway's, too, since 1814) was the constitution of 1809. Representative power had existed until 1866 in the form of four chambers, but a parliamentary democracy can be spoken about only as of 1917, after overcoming the old feudal system and establishing a constitutional monarchy with a bicameral parliament (see Beyme, 2011: 50-51). In Denmark, the constitution of 1849 limited the powers of parliament and extended freedom of the press and religion. In Finland, since 1907, i.e. still during the period of its autonomous position within Tsarist Russia, active suffrage (the right to vote) and, for the first time in the world, passive suffrage (the right to run for office) for women was introduced into practice. The inclination of Scandinavian countries towards the policy of a welfare state is connected with the enormous problems, the deep economic crisis and high unemployment in the 1920s and particularly in the first half of the 1930s, when the citizens of these countries decided to resolve their difficult situation by supporting social democratic parties. In Sweden, which in this period began building its welfare state, an agreement was reached in 1938 between the trade unions and the Social Democratic government, which arranged the autonomy of labour and capital bargaining on the basis of "strong interest groups as the best guarantee for social reconciliation". The further development of relations between the social partners was derived from this agreement, which can be considered as the basis of the Scandinavian social model.

According to historian Mary Hilson, "the 'social democratic welfare state' may be understood in two ways. "First, it describes welfare systems that, in their de-commodification of social relations and their emphasis on universalism and redistribution, embodied the social democratic ideological commitment to social equality and solidarity. Secondly, it suggests that the welfare state was the realization of the ideological programme of the social democratic parties that dominated Scandinavian politics during the second half of the twentieth century. As such, the Nordic welfare state should be acknowledged as the major political achievement of the organized working class. It was not, however, the sole achievement of the working class acting on its own but was instead a testament to the ability of the Scandinavian labour movements to form cross-class alliances with other social groups ..." (Hilson, 2008: 91-92). By expanding social services and employment in the public sector, the welfare state also directly shares in strengthening the middle class, which enjoys a privileged position on the labour market and was relatively successful in enforcing its social requirements. The Nordic Council, established in 1952, is the official body for formal inter-parliamentary co-operation among parliamentarians from its member nations. In 1954, the countries of Scandinavia created a passport union, and since that same year they have had a common labour market, which has enabled the citizens of any Scandinavian country to work freely within the entire region. There were also plans for a single market, but they were abandoned in 1959 shortly before Denmark, Norway and Sweden joined the European Free Trade Area. It was founded by seven countries: Denmark, Norway, Portugal, the UK and neutral Austria, 
Switzerland (including Liechtenstein) and Sweden. Later, Finland, Ireland and Iceland also became members. The association set the goal of achieving in its Member States sustainable economic growth, full employment, financial stability, and trade development by gradually eliminating mutual tariffs. ${ }^{3}$

\subsection{The social market economy}

The economic revival of Europe was to be accelerated by the Marshall Plan. This plan bears the name of US Secretary of State George C. Marshall, who in a speech at Harvard on 5 June 1947 stated that the United States had decided to provide organized assistance to post-war Europe. Marshall said in this speech: "Aside from the demoralizing effect on the world at large and the possibilities of disturbances arising as a result of the desperation of the people concerned, the consequences to the economy of the United States should be apparent to all. It is logical that the United States should do whatever it is able to do to assist in the return of normal economic health in the world, without which there can be no political stability and no assured peace. Our policy is directed not against any country or doctrine but against hunger, poverty, desperation, and chaos. Its purpose should be the revival of a working economy in the world so as to permit the emergence of political and social conditions in which free institutions can exist" (The Marshall Plan Speech, the State Department's handout version of June 4, 1947). The Marshall Plan was presented at a conference in Paris held from 12 July to 22 September 1947 and was approved by the US Congress on 3 April 1948. It contributed to a significant extent to speeding up the healing of war wounds and reviving the economy of Western Europe. This was component of American policy and definitively divided Europe into two power blocs.

Ideas about how to deal with Germany also formed in US political circles largely along with how the relations between Washington and Moscow developed. During the war, under the influence of US Secretary of Commerce Henry Morgenthau's opinions on Germany, President Roosevelt tried to push the hard line against Germany. He justified such an approach by saying that the entire German nation must understand that it had "led an illegal conspiracy against the rules of decency of modern civilization" (Manák, 2011: 150). Morgenthau's plan, which even focused on artificially reducing the living standards of Germans, was extremely drastic and at its core depraved. Secretary of War Henry Stimson in particular stood against this plan, saying that only a stabilized and economically strong Europe could withstand the influence of

\footnotetext{
${ }^{3}$ Although the cooperation among Scandinavian countries is no longer as it was in the past, and all of them have experienced some form of identity crisis, they are still typified by a participatory political culture that has a significant impact on effective performance of the state and the formation of anti-corruption policies. The United Kingdom, Ireland and Denmark were admitted to the European Community (EC) in 1973, which opened the door for closer cooperation and accession to the EC for other European Free Trade Association countries.
} 
Soviet communism. Washington definitively abandoned Morgenthau's plan after Roosevelt's death and the arrival of Harry Truman as president in April 1945. "After taking the Oval Office, Truman "surrounded himself with advisors who blamed Versailles, not the German people or German culture, for Germany's aggression. Mere important, members of the Truman administration relied on the notion of totalitarianism to link Germany's part with the Soviet, not the German, present. Still, Truman and his advisors remembered Germany's rise during the interwar period and ought to maintain control and limit its growth" (Etheridge, 2016: 64).

The strategic foreign policy pursued by the Truman administration was focused on the Containment of Communism, and therefore the involvement of defeated Germany in the European integration and post-war welfare consensus became a strong motivation against the increase of the Soviet influence in Europe. The first chancellor of the Bundesrepublik Deutschland (Federal Republic of Germany, FRG) was Konrad Adenauer, a representative of the Christian Democratic Union (Christlich Demokratische Union, CDU), who was elected federal chancellor on 15 September 1949 with a majority of only one vote. His political line found its closest partner in the Christian Social Union (Christlich-Soziale Union, CSU), which originated as the successor to the Bavarian People's Party. Adenauer, who held the position of Federal Chancellor until 1963, succeeded in pushing important treaties through the Federal Assembly during the first election period, ensuring the Western orientation of West Germany. The Social Democratic Party, which at the time was promoting neutrality, criticized Adenauer for insufficiently representing German interests, and its chairman, Kurt Schumacher, called him "the chancellor of the allies". Adenauer considered achieving the full sovereignty of West Germany and later unification with East Germany as the main goal of his policy. He was operating from political reality, however, and was convinced that the United States would be Germany's best ally.

Even after the founding of the Federal Republic of Germany how the long-term relations between France and Germany would evolve remained unclear. French Foreign Minister Robert Schuman was called upon by political representatives of the US and UK to submit a proposal for Germany's involvement in cooperating with Western European countries. American politicians advocated a policy that would allow the FRG, and thus its economic, political, and military relations, to become part of the Western bloc. Schuman chose not to support traditional French policy, in which the priority of the winners should be revenge towards a defeated Germany. He rather promoted new relations based on forgiveness over hatred and retaliation and did not reject the efforts of the US to offer economic aid to Germany.

When the Christian Democratic Union was founded in 1945, there was a demand that a system based on "true Christian socialism would need to be created" (Lienkamp, 2001: 204). Christian socialism became the basis of the Ahlener Programm, which was approved by the CDU on February 3, 1947 in the British zone. This Programm was critical of the capitalist economic system and supported the nationalization of key areas of industry as well as the 
economic planning. With the support of the Marshall Plan, the idea of a social market economy began being promoted in the FRG. With the adoption of the Düsseldorf Guidelines (Düsseldorfer Leitsätze) in 1949 the planned economy was corrected to the concept of a social market economy (Soziale Marktwirtschaft).

The system of Soziale Marktwirtschaft is theoretically associated with economists and lawyers of the Freiburg School and the origin of the term 'Soziale Marktwirtschaft' is attributed to Alfred Müller-Armack, professor of economics at the University of Münster and the University of Cologne, who used it in his publication Wirtschaftslenkung und Marktwirtschaft published shortly after the World War II (see Müller-Armack, 1990). However, in connection with Müller-Armack, his Behavior during the National Socialist dictatorship should also be mentioned. Already during Heinrich Brüning's reign, he criticized political pluralism and expressed his sympathy for Italian fascism. In 1933 Müller-Armack published his work Staatsidee und wirtschaftliche Ordnung im Neuen Reich, in which he welcomed the Nazi regime in the same year he became a member of the party. In the early 1940s, Müller-Armack met economist Ludwig Erhard in discussions of post-war concepts of economic order. And it was probably Erhard who mentioned the term "Soziale Marktwirtschaft" during these discussions. Ludwig Erhard, who stood the social market economy up against the socialist economy and the free market economy, is considered to be the "father of the economic miracle" (Wirtschaftswunder). He had the courage to push for monetary reform. By introducing the concept promoted by Erhard, the Federal Republic entered into a phase of active and successful interconnection of economic and social steps. He presented the social market economy as an economy that placed emphasis on its own initiative in the social field, while the care of society was to be focused mainly on those who would not be able to cope without help. "Prosperity for All" was what Erhard set out as his goal, and he therefore tried to motivate the citizens of the Federal Republic to take action with a challenge: "I want to prove myself on my own initiative. I want to bear life's risks myself, be responsible for my own fate. You, Country, should ensure that I am able to do so" (Erhard, 1958: 189-191). Ludwig Erhard was cautious towards the promotion of the Welfare State. In this regard, Erhard stressed: "My criticism about the disastrous pressure for a Welfare State must not be misunderstood as a wish to change social security as we know it. I believe that a further extension of social security is perfectly possible. But what I consider as totally wrong is that people who, having acquired freedom as a result of their profession and their position in the national economy, should wish to move into a collective scheme, or worse still, to be pushed into it" (Erhard, 1958: 191). The state's particular role, according to the social market economy concept, was to create the legal framework for creativity and for ensuring a suitable environment in which competition was of central importance. In a relatively short period of time the social market economy brought a high standard of living and a relatively high measure of social security to a broad spectrum of society. Of course, the SPD could not ignore that either. However, The West German 
Social Democratic Party especially in the period when it was led by Kurt Schumacher harshly criticized not only the economic and political development of Germany but also the Schuman Plan, which Schumacher described as the "biggest gamble" (Schumacher, March 31, 1951). Repeated defeats in the Bundestag elections forced the SPD to set out to change its image. And under the pressure of this fact an extraordinary SPD party congress in Bad Godesberg ratified on 15 November 1959 a new program by which the SPD changed itself from a socialist workers' party to a people's party. Central elements of the Godesberg program include the commitment to the social market economy.

\section{3 "Prosperity for the States of Europe and the social developments that must go with it..."}

As for the start of Western European integration, this is linked with the name of Jean Monnet. After the outbreak of World War II, Monnet was chairman of the Franco-British Coordinating Committee for Economic Coordination. He also advocated the creation of a Franco-British political union to combat Nazism. In the end, however, he did not succeed with this proposal. Monnet therefore offered his diplomatic experience to the British government and Winston Churchill sent him on a special mission to the United States, where he became one of the trusted advisers of President Roosevelt, even before the US entered the war. In 1943, Monnet went to Algiers, seat of the French Provisional Government and became its member. In the same year, Monnet presented its ideas on the possible peaceful future of Europe. From a historical point of view, this was a fundamental statement, as evidenced by the following words: "There will be no peace in Europe if the States are reconstituted on the basis of national sovereignty, with all that that entails in terms of prestige politics and economic protectionism. If the nations of Europe once again adopt defensive positions, huge armies will once again be necessary. ... Fear will once more be the dominant factor in European reconstruction. The countries of Europe are too small to guarantee their peoples the prosperity that modern conditions make possible and consequently necessary. They need larger markets. It is also important that they do not devote a substantial share of their resources to maintaining supposedly 'key' industries to meet the requirements of national defence, industries which are rendered obligatory by the form that States take, with their 'national sovereignty' and protectionist reflexes, such as we saw before 1939. Prosperity for the States of Europe and the social developments that must go with it will only be possible if they form a federation or a 'European entity' that makes them into a common economic unit" (Jean Monnet's thoughts on the future, August 5, 1943). Monnet is considered the Architect of post-war Planning for the French Economy. In 1945, he convinced President De Gaulle of supporting the Plan de Modernization et d'Équipement, and on January 3, 1946, the Commissariat général du Plan was established, with Monnet at its head. Like the British, post-war France has strengthened the state's position in the production system. Economic development as well as tax policy and price controls were influenced by the central power. However, these activities were to be implemented without disrupting a private initiative. "The 
Monnet Plan confined itself to providing government with a strategy and levers for actively fostering certain favoured objectives. At the time this was a strikingly original undertaking" (Judt, 2010: 71). This Plan assumed French access to German raw materials and markets, and it was Monnet who came up with a bold project proposal advocating that France and Germany's coal and steel production be "covered under the highest joint office in an organization that will be open to the participation of other European countries". Schuman shared Monnet's ideas about the development of Franco-German relations, and these ideas also received a positive response from West German chancellor Konrad Adenauer.

It is possible to agree that in his bold decision to support FrancoGerman cooperation Schuman was also inspired by personalist philosopher Jacques Maritain (1882-1973). His philosophical influence on post-war Christian thought is connected primarily with the field of cultural development and its quality on a democratic-personalistic basis (Maritain, 1946: 420). His integral humanism is built on a theocentric foundation and "by its very nature tends essentially to render man more truly human, and to manifest his original greatness by having him participate in all that can enrich him in nature and history" (Maritain, 1967: 10). In Maritain's view, radical changes will require the creation of new social structures and a new system of social life that does not bow to humanity, but "really and effectively respects human dignity and does justice to the integral demands of the person" (Maritain, 1967: 13-14). Maritain places great importance on professional groups and unions of citizens "who devote themselves to the development of democratic philosophy, education of the people in matters of common law and intellectual struggle against subversive political movements" (see Shestopal - Astakhova Astakhov, November 2015: 195-196).

According to Schuman, the clash of traditional national interests should also become a thing of the past, which should contribute to opening up the prospect of a new development of Europe, which could also be a herald for how the world of the twenty-first century should be organized (see Mandelbaum, 2002: 374). The Federal Republic of Germany, France and Italy, together with the Benelux countries (Belgium, the Netherlands and Luxembourg), created the European Coal and Steel Community. Schuman, Adenauer and Alcide de Gasperi in particular played major roles in establishing the common market for coal, steel, coke, iron ore and scrap, managed by the High Authority. They all came from the border areas of countries where identities had been "multiple in the long-term" and where borders had also shifted. These politicians saw the sense of cooperation in a joint project from both a cultural and a political and economic point of view. As Tony Judt stated: "they could reasonably see it as a contribution to overcoming the crisis of civilization that had shattered the cosmopolitan Europe of their youth“ (Judt, 2010: 157).

The goal of the Treaty of Paris (signed on 18 April 1951) establishing the European Coal and Steel Community (ECSC), which entered into force after ratification by the parliaments of its Member States in June 1952, was the gradual replacement of various national markets with a common market that 
would allow the free movement of goods, services, capital and labour within these sectors of the Member States. Cooperation built not only on political but also on value principles, however, recorded several critical situations from its origin, suggesting that the transfer of some competencies to a transnational level would not be so simple. Despite the positive response to the founding and operation of the ECSC, various reservations about its operation arose in both France and the Federal Republic of Germany.

Unlike the SPD, the French socialist party issued a statement welcoming the Schuman's plan in principle, but the central committee of the SFIO wanted to take a clear position when it would be possible to see its details. Many French socialists inspired by the Beveridge system, which was widely used in post-war France, assumed that the future in France belonged to the Socialists. Léon Blum, a long-term socialist leader and three times Premier of France who returned from German imprisonment, also dreamed about it. "Blum's dream of Socialist ascendancy was never realized; instead of S.F.I.O. had to suffer the indignities of a minor role in an unpopular and badly-knit alliance" (Graham, 1965/91: 2-3). Despite the fact that French Socialism in the years 1944-1947 passed through a period of turmoil and an internal crisis, political representatives of the French Socialist Party actively participated in the preparation of the economic and social reform program adopted on March 15, 1944 by the the Conseil National de la Résistance (National Council of the Resistance) entitled Les Jours Heureux (The Happy Days). Several French socialists were inspired by the Scandinavian welfare state model with universal benefits and strong public services such as education, child-care and active labor market policies. However, the political position of the French Socialists was very weak. And it should also be mentioned that unlike the Nordic counties, the French Socialists did not have a strong trade union partner on their side. The General Confederation of Labor (Confédération Générale du Travail, CGT), which was dominant in French trade unionism, became increasingly influenced by the French Communist Party, which was clearly shown in 1947, when communist ministers were expelled from the national government. After a wave of strikes, the socialists left the CGT and formed a new federation, the General Confederation of Labor-Workers' Force (Confédération Générale du Travail-Force Ouvrière), in 1948 (see Katuninec, 2009: 77-78).

André Philip, one of the party's staunchest supporters of trade liberalization and European integration, argued already to the party's National Council in 1948 that a "customs union ought to be accompanied by the unity of legislation as it concerns fiscal policy, salaries, social security and monetary policy". Historian Brian Shaev, who focuses on the transnational relations of socialist parties in Europe, emphasizes in this connection that "the demand for the harmonization of social policies became a staple of French Socialist policy towards proposals for European unity through the 1950s." The Schuman Plan defined by Jean Monnet certainly gained support in the SFIO also because its leaders enjoyed close, personal relations with Monnet. In connection with the Schuman Plan and the post-war process of European unification, Catholic politicians and thinkers have already played an important role. However, fears 
that this was a Catholic activity were unfounded. Andre Philip, who advocated an alliance between the center-left and the center-right parties, was not only a prominent post-war socialist politician, but also actively served as chairman of the Commission for on International Affairs of the Federation Protestant of France he had created in 1943, and "some churchmen claimed that the Schuman Plan followed Phillip's ideas" (Leuștean, 2014: 24).

If we want to talk about important pro-European socialist politicians who have not given up even in the most difficult situations and have shown how important political figures were in practical politics, we must mention the Belgian Paul-Henri Spaak. This influential Belgian Socialist politician, diplomat and statesman, had as early as 1944 as the Belgian Foreign Minister in exile in London, proposed the creation of an alliance between Belgium, Luxembourg and the Netherlands (Benelux), which took place in September of the same year with the signing of the Common Customs Union. Spaak was convinced that the integration of countries through binding treaty obligations is the most appropriate means of guaranteeing peace and stability. He has been active in several international organizations and has also played an important role in the negotiation of the Treaties of Rome. In March 1956, at a special session of the European Coal and Steel Community, Spaak submitted a document that was approved by the Council of Ministers after multiple discussions. Not quite one year later, after the elaboration of several comments, the Treaties of Rome, which can be considered an important milestone in European integration, were prepared for signing. Upon their entry into force in January 1958, the Treaties of Rome formed the basis for the existence of the European Economic Community (EEC) and the European Atomic Energy Community (EURATOM). Together with the Treaty of Paris (1951), the Treaties of Rome remain the most important legal basis in what is now the European Union (EU).

\section{Conclusion}

Although there has never been a coherent model of the welfare state in a democratic Europe, trust in democracy and its institutions is closely linked to social rights, income security, eradication of poverty and other issues defining social policy as a central entity (see Esping-Andersen, 1990: 16; Martinkovič, 2016: 50). The process of European integration from the beginning has been led by the idea of the need to strike a balance between the economic and social dimensions. Increasing the living standards and working conditions of employees was the common goal of all its members. In this context, they also emphasized the principles of solidarity and subsidiarity on the ground. The welfare state was characterized by its stability and up until the mid-1970s it was manifested in relative peace in economic and social stability. Under changed conditions, however, it was hit by several shocks (see Fisch, 1996). The ending of an era of extraordinary economic and social development was due primarily to the unexpected rise in oil prices. The period of the oil crisis, in which the world economy fell into a deep recession, revealed the weaknesses of the post- 
war dream of sustainable economic growth and social stability. "Western Europe's thirty glorious years 'gave way to an age of monetary inflation and declining growth rates, accompanied by widespread unemployment and social discontent" (Judt, 2010: 453). The change in the social climate took a relatively long time. Several Western European countries tried to resist by increasing debt, but they could not escape the crisis of the "welfare state" and had to contend with rising inflation, unemployment, poverty and economic recession. The European Union has since overcome many crises and the welfare state had to face battles for survival on various fronts. "Despite constant discussions about the 'crisis of legitimacy' of the welfare state, as well as the need and universality of social reforms already implemented or intended, which increasingly reduce it, support for the meaning and function of the welfare state and its social policy remains relatively strong among citizens of all European countries“ (Čambáliková, 2020: 139).

Even today, there are various opinions about the future of the welfare state in continental Europe. In EU, the coronavirus COVID-19 pandemic again has raised new questions but forecasting the course of welfare state has proved supremely difficult already many times. Several theorists and politicians say that the pandemic can be considered a turning point, or the beginning of a fundamental transformation of the whole European project. We don't know what kind of surprises the future holds for us, and it is very difficult to predict today how a pandemic will affect the development of our continent. These days, however, we can better realize what is truly essential, important and irreplaceable in life. Despite the difficult times, this is a crisis thanks to which society can find out how closely connected it is and how highly people are dependent on each other (see Krastev, 2020: 93).

\section{References}

Beveridge Report. (November 1942). Three Guiding Principles of Recommendations. In The National Archives. [online]. [cit.2020-0108].Available:https://www.nationalarchives.gov.uk/education/resourc es/attlees-britain/ Beveridge-report/

Beyme, K. (2011). Representative democracy and the populist temptation. In Alonso, S. - Keane, J. - Merkel, W.: The Future of Representative Democracy. Cambridge: Cambridge University Press, 2011, pp 50-73. Online ISBN: 9780511770883. [cit.2020-01-08]. Available: https://doi.org/10.1017/CBO9780511770883.

Brief summary of the Second International Conference for the United Socialist States of Europe (21-22 June 1947). In CVCE.eu by uni.lu - Digital collections on History of the European Integration. Source: Unite or Perish - Report of International Conference Paris (June 21 and 22, 1947), Report of the Second International Conference for the United Socialist States of Europe, Paris, 21 and 22 June. London-Paris: InternationalCommittee of Study and Action for the United Socialist States of Europe. 143 p. [online]. [cit.2020-01-08]. 
Available:https://www.cvce.eu/obj/brief_summary_of_the_second_in ternational_conference_for_the_united_socialist_states_of_europe_21 _22_june_1947-en-d1f291b5-bf84-4ee1-9fd5-7661de97632.html

Čambáliková, M. (2020). Sociálny štát a sociálne občianstvo: Quo vadis? (Social State and Social Citizenship: Quo Vadis?). In Politické Vedy/ Political Sciences, 23 (1), 2020, pp. 123-141. ISSN 1335-2741. [online]. [cit.2020-01-08]. Available: http://doi.org/10.24040/politickevedy.2020.23.1.123-141.

Dennehy, R. (2004). Can Jacques Maritain Save Liberal Democracy from Itself? In Trapani, J. G. (ed.) Truth Matters: Essays in Honor of Jacques Maritain. Washington, D.C.: The Catholic University of America Press, pp. 257-269. ISBN 0-9669226-6-2.

Erhard, L. (1958). Prosperity Through Competition. New York: Frederick A. Praeger, 263 p. ISBN 978-1-933550-87-9.

Esping-Andersen, Gøsta. (1990/1998). The three worlds of welfare capitalism. Princeton, New Jersey: Princeton University Press, 248 p. ISBN 0-69102857-5.

Etheridge, B. C. (2016). Enemies to Allies. Cold War Germany and American Memory. Lexington: The University of Kentucky, 382 p. ISBN 9780813166407.

Gerbet, P. (2004). Budování Evropy. Praha: Karolinum, 450 p. ISBN: 80-2460111-7.

Graham, B. D. (1965/1991). The French Socialists and Tripartisme 1944-1947. Canberra: The Australian National University, [online] [cit.2020-0108].Available:https://openresearchrepository.anu.edu.au/bitstream/188 5/114771/2/b10894330.pdf

Hilson, M. (2008/2013). The Nordic Model. Scandinavia since 1945. London: Reaktion Books. 234 p. ISBN 978-1-86189-366-6.

Jean Monnet's thoughts on the future (5 August 1943). Source: Fondation Jean Monnet pour l'Europe, Lausanne. Archives Jean Monnet. Fonds AME. 33/1/4. [online]. [cit.2020-01-08]. Available: https://www.cvce.eu/content/publication /1997/ 10/13/b61a8924-57bf4890-9e4b-73bf4d882549/publishable_en. pdf

Judt, T. (2010). Postwar: A History of Europe Since 1945. London: Vintage Books, 933 p. ISBN 978-0-099-54203-2.

Katuninec, M. (2009). Medzinárodné odborové centrály a zastupovanie zamestnancov na podnikovej a nadpodnikovej úrovni v niektorých krajinách Európskej únie. Trnava: Filozofická fakulta, Trnavská univerzita v Trnave, 120 p. ISBN 978-80-8082-273-6.

Katuninec, M. (2020). Welfare State vs. Warfare State. In AD ALTA: Journal of Interdisciplinary Research. 10 (2), pp. 176-180. ISSN 2464-6733. [online] [cit.2021-09-01]. Available: www.doi.org/10.33543/1002

Krastev, I. (2020). Európa a Pandémia. Žilina: Absynt, 102 p. ISBN 978-808203-183-9.

Lienkamp, A. (2001). Socialism out of Christian Responsibility. The German Experiment of Left Catholicism (1945-1949). In Horn, G. R. - Gerard, 
E. (eds.): Left Catholicism, 1943-1955: Catholics and Society in Western Europe at the Point of Liberation. (KADOC Studies 25). Leuven: Leuven University Press, pp. 196-227. ISBN 9058670937.

Leuștean, L. N. (2014). The Ecumenical Movement and the Making of the European Community. Oxford, UK: Oxford University Press, 286 p. ISBN 979-0-19-871456.

Manák, M. (2011). Európska poradná komisia a diplomacia USA v rokoch 1943-1945. Trnava: Filozofická fakulta. Trnavskej univerzity v Trnave, 224 p. ISBN 978-83-7490-436-0.

Mandelbaum, M. (2002). The Ideas That Conquered the World: Peace, Democracy, and Free Markets in the Twenty-first Century. New York: Public Affairs Press. 512 p. ISBN 1586481347.

Maritain J. (1946). The Person and the Common Good. (trans. John J. Fitzgerald) In The Review of Politics, 8 (4), pp. 419-455. Available: https://doi.org/10.1017/S0034670500045101; http://www.sfu.ca/classics/pdf/person.pdf

Maritain, J. (1967). Integrální humanismus. Řím: Křest'anská akademie, 305 p. Martinkovič M. (2016). Moral Aspects of Politics and their Relation to the Legitimacy of Liberal Democracies. In Katuninec, M., Martinkovič, M.: Ethical and Social Aspects of Policy: Chapters on Selected Issues of Transformation. Frankfurt am Main, Berlin: Peter Lang, 2016, pp. 39-62. ISBN 9783631671580.

Schumacher, K. (1947). Deutschland und Europa. In Protokoll der Verhandlungen des Parteitages der Sozialdemokratischen Partei Deutschlands vom 29. Juni bis 2. Juli 1947 in Nürnberg. Ham- burg: Auerdruck GmbH, 1947, pp. 35-56. [online]. [cit.2020-01-08]. Available: http://library.fes.de/parteitage/pdf/pt-jahr/pt-1947.pdf

Schumacher, K. (1951). Make Europe strong! Paper given by Kurt Schumacher on the Schuman Plan. Source: Schumacher, K.: Macht Europa stark! Referat in der gemeinsamen Sitzung des Parteivorstandes, des Parteiauschusses, der Kontrollkommission und des Vorstandes der Bundestagsfraktionder SPD am Sonnabend, dem 31. März 1951, in Bonn. Hannover: Vorstand der SPD, 1951. 32 p. Archiv der sozialen Demokratie der Friedrich-Ebert-Stiftung. [online]. [cit.2020-01-08]. Available:

http://www.cvce.eu/obj/paper_given_by_kurt_schumacher_on_ the_schuman_plan_bonn_31_march_1951-en-b36cebda-e613-4bffa263-aacfda84c410.html

Shestopal, S. S. - Astakhova, K. V. - Astakhov, V. V. (2015). Modern Dimensions of Jacques Maritains Political and Legal Personalism. In Mediterranean Journal of Social Sciences. Rome: MCSER Publishing, 6 (6), November 2015, pp. 192-197. Online ISSN 2039-2117. [cit.2020-01-08]. Available: 10.5901/ mjss.2015.v6n6s3p192

Social Insurance and Allied Services. Report by sir William Beveridge, (Cmd 6404). London: His Majesty's Stationery Office, (1942). [online]. 
[cit.2020-01-08].

Available: http://news.bbc.co.uk/2/shared/bsp/hi/pdfs/19_07_05_beveridge.pdf

Ştefan, G. M. (2015). European Welfare State in a Historical Perspective. A Critical Review. In European Journal of Interdisciplinary Studies, 7 (1), pp. 25-38. [online] [cit.2020-01-08]. Available: https://www.questia.com/library/ p439876/european-journal-ofinterdisciplinary-studies/i4509102/ vol-7-no-1-june

The Marshall Plan Speech (from the State Department's handout version of June 4, 1947). In George C. Marshall Foundation. Available: https://www.marshallfoundation.org/ marshall/the-marshallplan/marshall-plan-speech/

Veber, V. (2012). Dẽjiny sjednocené Evropy. Praha: Nakladatelství Lidové noviny, 830 p. ISBN 978-80-7422-183-5. 